\title{
Increase in Serotonin-1A Autoreceptors in the Midbrain of Suicide Victims with Major Depression-Postmortem Evidence for Decreased Serotonin Activity
}

\author{
Craig A. Stockmeier, ${ }^{1,2}$ Laura A. Shapiro, ${ }^{1}$ Ginny E. Dilley, ${ }^{1}$ Tamara N. Kolli, ${ }^{1}$ Lee Friedman, ${ }^{1}$ and \\ Grazyna Rajkowska ${ }^{3}$ \\ ${ }^{1}$ Program in Basic and Clinical Neuroscience, Department of Psychiatry, and 2Department of Neuroscience, Case \\ Western Reserve University, Cleveland, Ohio 44106, and ${ }^{3}$ Department of Psychiatry and Human Behavior, University of \\ Mississippi Medical Center, Jackson, Mississippi 39216
}

It has been hypothesized that a deficit in serotonin may be a crucial determinant in the pathophysiology of major depression. Serotonin-1A receptors are located on serotonin cell bodies in the midbrain dorsal raphe (DR) nucleus, and the activation of these receptors inhibits the firing of serotonin neurons and diminishes the release of this neurotransmitter in the prefrontal cortex. Repeated treatment with some antidepressant medications desensitizes serotonin-1A receptors in the rat midbrain. The present study determined whether the binding of $\left[{ }^{3} \mathrm{H}\right] 8$-hydroxy-2-(di-n-propyl)aminotetralin (8-OH-DPAT), an agonist at serotonin-1A receptors, is altered in the midbrain of suicide victims with major depression. Radiolabeling of the serotonin-1A receptor in the DR varied significantly along the rostral-to-caudal extent of the human midbrain. The binding of $\left[{ }^{3} \mathrm{H}\right] 8-\mathrm{OH}-\mathrm{DPAT}$ to serotonin-1A receptors was increased significantly in the midbrain DR of suicide victims with major depression as compared with psychiatrically normal control subjects. In suicide victims with major depression, the increase in the binding of $\left[{ }^{3} \mathrm{H}\right] 8-\mathrm{OH}-D P A T$ to serotonin-1A receptors was detected in the entire DR and specifically localized to the dorsal and ventrolateral subnuclei. Enhanced radioligand binding of an agonist to inhibitory serotonin-1A autoreceptors in the human DR provides pharmacological evidence to support the hypothesis of diminished activity of serotonin neurons in suicide victims with major depression.

Key words: serotonin-1A receptors; dorsal raphe nucleus; major depression; suicide; postmortem brain
Serotonin appears to play a key role in major depression and suicidality. Early evidence relating major depression to a decrease in serotonin neurotransmission comes from clinical observations that treatment with reserpine, a drug that depletes monoamine neurotransmitters, evoked clinical symptoms very similar to major depression (Quetsch et al., 1959; Peterfy et al., 1976). Conversely, the symptoms of major depression are relieved by chronic treatment with medications that potentiate serotonergic activity by preventing either the reuptake or the metabolism of serotonin (for review, see Montgomery, 1995).

Imaging studies suggest a role for the midbrain, a concentrated source of serotonin cell bodies, in the pathophysiology of major depression. In a study that used ultrasound imaging, subjects with major depression exhibited a significant trait-dependent decrease in the reflection of ultrasound waves by the midbrain and pontine raphe as compared with normal controls, subjects with bipolar affective disorder, or subjects with schizophrenia (Becker et al., 1995). Evidence for brainstem involvement in major depression has been demonstrated in a recent imaging study that showed that

Received May 14, 1998; revised June 22, 1998; accepted June 29, 1998.

This work was supported by grants from the National Institute of Mental Health (MH45488) and The American Foundation for Suicide Prevention. We gratefully acknowledge the work of Herbert Y. Meltzer, M.D., and James C. Overholser, $\mathrm{Ph} . \mathrm{D}$., in the retrospective psychiatric diagnoses. The excellent assistance of the Cuyahoga County Coroner's Office, Cleveland, $\mathrm{OH}$, is greatly appreciated. Helpful conversations with Gregory Ordway, Ph.D., and the technical assistance of Jinrong Wei are gratefully noted.

Correspondence should be addressed to Craig Stockmeier, Ph.D., Department of Psychiatry, Hanna Pavilion B-68, University Hospitals of Cleveland, 11100 Euclid Avenue, Cleveland, OH 44106-5078.

Copyright (ㄷ) 1998 Society for Neuroscience $\quad 0270-6474 / 98 / 187394-08 \$ 05.00 / 0$ patients with major depression had a significant decrease in radioligand binding to the serotonin transporter in the midbrain (Malison et al., 1997).

Other research in completed suicide or suicide attempts provides evidence for reduced serotonin function in these individuals. In most, but not all, studies the content of serotonin or its metabolite, 5-hydroxyindoleacetic acid (5-HIAA), is decreased in the brainstem of suicide victims (Shaw et al., 1967; Bourne et al., 1968; Pare et al., 1969; Lloyd et al., 1974; Beskow et al., 1976; Cochran et al., 1976; Korpi et al., 1986). Suicidal behavior is associated with lower levels of 5-HIAA in the CSF, and there is evidence that suicide risk can be predicted by low 5-HIAA in CSF after a suicide attempt (Nordstrom and Asberg, 1992). Finally, low serotonergic activity, as measured by the level of 5-HIAA in the cerebrospinal fluid, is associated with planned and more medically damaging suicide attempts in depressed patients (Mann et al., 1996).

Animal studies reveal that serotonin-1A receptors located on serotonin cell bodies in the midbrain influence the release of serotonin in the prefrontal cortex. These receptors inhibit the firing of serotonin neurons and diminish the release of this neurotransmitter in prefrontal cortex (Aghajanian et al., 1987). Serotonin-1A receptors in the midbrain are desensitized by chronic treatment with antidepressant medications such as monoamine oxidase inhibitors and selective serotonin reuptake inhibitors (SSRIs) (Blier and De Montigny, 1994; Invernizzi et al., 1994). Therefore, changes in serotonin-1A receptors in the human midbrain may alter the release of serotonin in prefrontal cortex and thereby play a significant role in major depression. 


\begin{tabular}{|c|c|c|c|c|c|c|c|}
\hline Sample & $\begin{array}{l}\text { Age/ } \\
\text { gender }\end{array}$ & Cause of death & $\begin{array}{l}\text { PMI } \\
\text { (hr) }\end{array}$ & Toxicology & Smoker & Medication & AXIS I diagnosis \\
\hline Control & $27 / \mathrm{m}$ & $\begin{array}{l}\text { Electrocution by } \\
\text { lightning }\end{array}$ & 22 & Nothing detected & Yes & & $\begin{array}{l}\text { No diagnosis, alcohol } \\
\text { abuse }>7 \text { years ago }\end{array}$ \\
\hline Control & $40 / \mathrm{m}$ & Cardiovascular disease & 22 & Lidocaine & Yes & & $\begin{array}{l}\text { No diagnosis, alcohol } \\
\text { abuse }>2 \text { years ago }\end{array}$ \\
\hline Control & $44 / \mathrm{m}$ & $\begin{array}{l}\text { Cardiovascular disease, } \\
\text { aortic aneurism }\end{array}$ & 6 & $\begin{array}{l}\text { Ephedrine, phenylpro- } \\
\text { chlorpheniramine }\end{array}$ & No & & No diagnosis \\
\hline Control & $45 / \mathrm{f}$ & Cardiovascular disease & 9 & Nothing detected & Yes & & No diagnosis \\
\hline Control & $47 / \mathrm{m}$ & Cardiovascular disease & 17 & Nothing detected & Yes & famotodine & No diagnosis \\
\hline Control & $50 / \mathrm{m}$ & Cardiovascular disease & 26 & Nothing detected & Yes & & No diagnosis \\
\hline Control & $57 / \mathrm{m}$ & Cardiovascular disease & 10 & Nothing detected & $\mathrm{Hx}$ & naproxen & No diagnosis \\
\hline Control & $58 / \mathrm{m}$ & Cardiovascular disease & 22 & Nothing detected & Yes & digoxin & No diagnosis \\
\hline Control & $69 / \mathrm{m}$ & Cardiovascular disease & 18 & Nothing detected & No & & No diagnosis \\
\hline Control & $82 / \mathrm{m}$ & $\begin{array}{l}\text { Cardiovascular disease, } \\
\text { aneurism }\end{array}$ & 16 & Nothing detected & No & levothyroxine & No diagnosis \\
\hline Suicide & $25 / \mathrm{f}$ & Hanging & 17 & Nothing detected & & $\begin{array}{l}\text { Nortriptyline, Perphenazine, } \\
\text { clonidine }\end{array}$ & Major depression \\
\hline Suicide & $30 / \mathrm{m}$ & Sigsw-chest & 18 & Ethanol $0.07 \%$ blood & Yes & & $\begin{array}{l}\text { Major depression, alcohol } \\
\text { abuse } 2 \text { years ago }\end{array}$ \\
\hline Suicide & $42 / \mathrm{m}$ & Sigsw-chest & $>20$ & Nothing detected & & & Major depression \\
\hline Suicide & $43 / \mathrm{m}$ & Hanging & 21 & Nothing detected & No & & Major depression \\
\hline Suicide & $45 / \mathrm{m}$ & Multiple knifing & 8 & Nothing detected & & $\begin{array}{l}\text { Nifedipine, allopurinol, } \\
\text { corzide }\end{array}$ & $\begin{array}{l}\text { Major depression, } \\
\text { dysthymia }\end{array}$ \\
\hline Suicide & $48 / \mathrm{m}$ & $\begin{array}{l}\text { Sigsw-chest, slashed } \\
\text { wrists }\end{array}$ & 21 & Flurazepam & No & Flurazepam, Lorazepam & $\begin{array}{l}\text { Major depression, alcohol } \\
\text { abuse } 24 \text { years ago }\end{array}$ \\
\hline Accident* & $54 / \mathrm{m}$ & Carbon monoxide & 23 & $\begin{array}{l}\text { Carbon monoxide, phenobar- } \\
\text { bital, phenytoin }\end{array}$ & $\mathrm{Hx}$ & Sertraline & Major depression \\
\hline Suicide & $62 / \mathrm{m}$ & Hanging & 5 & Nothing detected & Yes & $\begin{array}{l}\text { traz, nortriptyline, } \\
\text { sertraline }\end{array}$ & $\begin{array}{l}\text { Major depression, alcohol } \\
\text { abuse } 4 \text { years ago }\end{array}$ \\
\hline Suicide & $70 / \mathrm{m}$ & Sigsw-head & 23 & Phentoin-acute & & $\begin{array}{l}\text { doxepin, prednisone, } \\
\text { captopril }\end{array}$ & $\begin{array}{l}\text { Major depression, alcohol } \\
\text { dependence } 15 \text { years } \\
\text { ago }\end{array}$ \\
\hline Suicide & $83 / \mathrm{f}$ & Slashed wrists & 21 & Nothing detected & & temazepam & Major depression \\
\hline
\end{tabular}

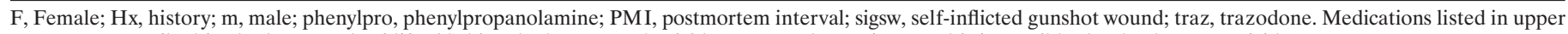
case were prescribed in the last month of life. *Subject had attempted suicide on several occasions, and it is possible the death was a suicide.

The purpose of this study was to test the hypothesis that serotonin-1A receptors are increased in the dorsal raphe (DR) of suicide victims with major depression. The midbrain was sampled at several rostral-to-caudal levels, and quantitative receptor autoradiography was used to measure serotonin-1A receptors. Retrospective psychiatric assessments were used to select psychiatric subjects with a current episode of major depression and comparison subjects determined to be psychiatrically normal.

\section{MATERIALS AND METHODS}

Subjects. Brain tissue was obtained at autopsies performed at the Cuyahoga County Coroner's Office, Cleveland, OH. The study was performed in compliance with policies of an institutional review board, and written consent was obtained from the next-of-kin. Midbrains were collected from 10 suicide victims and 10 age-matched ( \pm 5 years) comparison subjects dying of natural or accidental causes. The causes of death were certified by the County Coroner and are listed in Table 1 . Both tissues and the resultant autoradiograms from the matched pairs of subjects were coded and then processed and analyzed in parallel.

The toxicology laboratory of the County Coroner's Office examined blood and urine samples from the subjects. Qualitative and quantitative assays were used to detect the compounds and their metabolites, as previously described (Stockmeier et al., 1997). The results of the toxicology testing are listed in Table 1.

Retrospective psychiatric diagnoses. Retrospective psychiatric assess- ments were used as previously described to identify control subjects without a mental illness and suicide victims with a current diagnosis of major depression (Stockmeier et al., 1997). Kelly and Mann (1996) recently have validated the use of psychological autopsy by demonstrating good agreement between informant-based retrospective psychological assessments of deceased subjects and chart diagnoses generated by clinicians treating the same subjects before death. In the current study, $\sim 3$ months after death, a trained interviewer administered a structured interview with a knowledgeable informant for all 20 of the subjects to collect information for determining the presence or absence of psychiatric disorders. Knowledgeable informants either lived with or had frequent weekly contact with the subjects before death. Data on lifetime and current mental illness were gathered with a modified Schedule for Affective Disorders and Schizophrenia: Lifetime version (SADS-L; Spitzer and Endicott, 1978). Diagnoses for Axis I disorders were assessed independently by a clinical psychologist and psychiatrist, and consensus diagnosis was reached in conference, using all available information from the knowledgeable informants, the coroner's office, and previous hospitalizations and doctors' records. The final diagnosis was compatible with the Diagnostic and Statistic Manual of Mental Disorders-Revised (DSMIII-R; American Psychiatric Association, 1987). The psychiatric diagnoses are summarized in Table 1.

The suicide victims met diagnostic criteria for a current history of major depression during the last month of life. One suicide victim with major depression also had a current comorbid diagnosis of dysthymia. There was no current psychoactive substance disorder (abuse or dependence) in any of the subjects. Three suicide victims previously met 
diagnostic criteria for alcohol abuse at 2, 4, and 24 years before death. Another suicide victim met diagnostic criteria for alcohol dependence at 15 years before death. Two psychiatrically normal control subjects met criteria for alcohol abuse at 7 and $>2$ years before death.

Tissues and immunohistochemistry. The midbrains were isolated from the brainstem by making a transverse cut along a line from the rostral border of the superior colliculus to the exit point of the oculomotor nerve. A second cut at the level of the isthmus was made along a line from the caudal extent of the inferior colliculus (at the exit of the trochlear nerve) through the pontine tegmentum. Tissues were frozen in isopentane cooled by solid $\mathrm{CO}_{2}$ and stored at $-80^{\circ} \mathrm{C}$ until the assays were performed. Tissue samples were coded to conceal the diagnostic group of the subjects.

The midbrain blocks were mounted on pedestals with Tissue-Tek (Miles, Elkhart, IN), and frozen sections were cut at $-15^{\circ} \mathrm{C}$ with a microtome (IEC, Needham Heights, MA). Sections for serotonin-1A receptor autoradiography were cut at $20 \mu \mathrm{m}$ thickness, and serial sections for tryptophan hydroxylase (TrpOH) immunohistochemistry were cut at $30 \mu \mathrm{m}$ thickness. Sections were thaw-mounted onto cold microscope slides coated with gelatin/chrom-alum, dried under a stream of roomtemperature air, and refrozen at $-80^{\circ} \mathrm{C}$. At $0.5 \mathrm{~mm}$ intervals along the block of tissue, sections were taken for both immunohistochemistry and receptor autoradiography. Slides for TrpOH immunohistochemistry were used to identify anatomically comparable rostral-caudal levels for analysis and to localize the subnuclei of the DR, as described by Baker et al. (1990, 1991). From a rostral-to-caudal direction, corresponding levels between subjects were identified by using the following description of anatomical landmarks. At level $\mathrm{A}$, the oculomotor nucleus and the dorsal and ventral subnuclei of the DR (DRd, DRv) were present. At level B, the oculomotor nucleus was absent, and the trochlear nucleus appeared. The interfascicular subnucleus (DRif) was present at level B. Level C revealed a prominent trochlear nucleus that was traversed by the trochlear nerve and its root. The ventrolateral subnucleus (DRvl) of the DR appeared and extended laterally at this level. The trochlear nucleus and DRvl were present at level D. At level E, the trochlear nucleus was absent, and the DRvl was less prominent and located more medially than at level C. Level F included the compact interfascicular nucleus, the decussating fibers of the superior cerebellar peduncles, DRd and DRv, and the most rostral traces of the LC. In level G, the median raphe nucleus was present and penetrated by the decussating fibers of the superior cerebellar peduncles. Level $\mathrm{H}$ was similar to level $\mathrm{G}$, except that the median raphe nucleus was more or less penetrated by the decussating fibers of the superior cerebellar peduncles. Level $\mathrm{H}$ included the caudal subnucleus of the DR (DRc) that extended both medially and laterally in the ventral direction. Level I included the LC, median raphe nucleus, fourth ventricle, medial longitudinal fasciculus, and the DRc. A randomly selected midbrain was used as a standard to which the rostral-to-caudal levels of the other midbrains were compared and with which they were set in register. Although the midbrain consistently was blocked and dissected from each subject, there were slight variations in the rostral-tocaudal appearance and disappearance of the various subnuclei of the DR in the 20 subjects. Hence, the most rostral and most caudal levels of the midbrain are not presented in Figure 2.

Receptor autoradiography. Radioligand binding to serotonin-1A receptors was determined autoradiographically, as described by Stockmeier et al. (1996), using the serotonin-1A receptor agonist $\left[{ }^{3} \mathrm{H}\right] 8$-hydroxy-2-(di$n$-propyl)aminotetralin (8-OH-DPAT). After a $30 \mathrm{~min}$ preincubation at room temperature in buffer $\left(\mathrm{pH} 7.7\right.$ at $\left.24^{\circ} \mathrm{C}\right)$ containing $170 \mathrm{~mm}$ Tris$\mathrm{HCl}, 4 \mathrm{mM} \mathrm{CaCl}$, and $0.01 \%$ ascorbic acid, three sections were incubated in fresh buffer for $1 \mathrm{hr}$ at $24^{\circ} \mathrm{C}$ with $\left[{ }^{3} \mathrm{H}\right] 8-\mathrm{OH}-\mathrm{DPAT}$ (2 nM, 154.3 $\mathrm{Ci} / \mathrm{mmol}$; New England Nuclear, Boston, MA). Nonspecific binding was measured in duplicate serial sections coincubated with $10 \mu \mathrm{M}$ serotonin (serotonin creatinine sulfate complex; Sigma, St. Louis, MO). Citalopram-hydrobromide ( $1 \mu \mathrm{M}$; Lundbeck, Copenhagen, Denmark) was included in the incubation with $\left[{ }^{3} \mathrm{H}\right] 8-\mathrm{OH}-\mathrm{DPAT}$ because there is evidence in rat striatum as well as bovine DR that $\left[{ }^{3} \mathrm{H}\right] 8-\mathrm{OH}-\mathrm{DPAT}$ binds to the serotonin transporter in addition to the serotonin-1A receptor (Alexander and Wood, 1988; Sprouse et al., 1993).

After the incubation the sections were washed twice at $4^{\circ} \mathrm{C}$ for $5 \mathrm{~min}$ each in the same (nonradioactive) buffer $\left(\mathrm{pH} 7.7\right.$ at $\left.4^{\circ} \mathrm{C}\right)$. Sections were dipped in ice-cold water, air-dried, and stored for $24-48 \mathrm{hr}$ at $4^{\circ} \mathrm{C}$ in sealed slide boxes with Drierite capsules. The sections and tritiated plastic standards (American Radiolabeled Chemicals, St. Louis, MO) that had been calibrated to brain mash were apposed to Hyperfilm- ${ }^{3} \mathrm{H}$ (Amersham, Arlington Heights, IL) in x-ray cassettes for 1 week. Films were processed with Kodak D-19 developer and fixed with Kodak Rapid Fix (Eastman Kodak, Rochester, NY).

Autoradiographic images of radioligand binding in the DR were digitized and quantitated with the Microcomputer Controlled Imaging Device (MCID; Imaging Research, St. Catharine's, Ontario, Canada). The subnuclei of the DR were identified by the cellular criteria of Baker et al. $(1990,1991)$ with a projection microscope in slides immunohistochemically stained for TrpOH. The borders of the subnuclei were drawn on paper, and digital templates of the borders were constructed from digitized images of the TrpOH immunohistochemistry. The digital templates of the borders were superimposed by MCID on autoradiographic images of serotonin-1A receptor binding. For each section, serotonin-1A receptors were measured in the entire midline DRif and the left half of each of the other subnuclei as well as in a composite image of these subnuclei. Total binding of $\left[{ }^{3} \mathrm{H}\right] 8-\mathrm{OH}-\mathrm{DPAT}$ was quantified and regarded as specific binding, inasmuch as nonspecific binding was nearly indistinguishable from film background.

Data analysis and statistics. Ten matched pairs of controls and suicide victims were used for the group-by-level analysis of $\left[{ }^{3} \mathrm{H}\right] 8-\mathrm{OH}-\mathrm{DPAT}$ binding to serotonin-1A receptors. There were five dependent variables, each measured at three to five levels (see Fig. 2; whole, levels C-G; ventrolateral, levels E-G; dorsal, levels D-G; interfascicular, levels C-G; and ventral, levels D-G), for a total of 21 measurement sites.

Because the specimens were processed as age-matched pairs of controls and suicide victims, a paired ANOVA analysis was performed, with two within-subjects (repeated measures) factors, i.e., group and level. Statistically significant group-by-level interactions were followed up with paired Student's $t$ tests at each level to determine the rostral-caudal location of any group differences. The ages and postmortem intervals (time between death and freezing of the tissue) of the two groups of subjects ( $n=10$ per group) were compared with paired Student's $t$ tests. An ANCOVA also was performed, with age and postmortem interval as covariates. The results of the ANCOVA were not substantially different from the ANOVA with repeated measures (data not shown).

\section{RESULTS}

The binding of $\left[{ }^{3} \mathrm{H}\right] 8-\mathrm{OH}-\mathrm{DPAT}$ to serotonin-1A receptors was measured in 10 pairs of psychiatrically normal control subjects and age-matched suicide victims with major depression. Characteristics of the subjects are presented in Table 1. The average age of the control subjects was $52 \pm 5$ years (mean \pm SEM), and that of the suicide victims was $50 \pm 6$ years. The average postmortem interval of the control subjects was $17 \pm 2 \mathrm{hr}$ and of the suicide victims was $18 \pm 2 \mathrm{hr}$. There was no significant difference between subject groups for either age or postmortem interval.

The specific binding of $\left[{ }^{3} \mathrm{H}\right] 8$-OH-DPAT is highly localized to the DR in the human midbrain. For orientation, a schematic drawing of the midbrain DR and its subnuclei is presented in Figure 1. As observed previously (Stockmeier et al., 1996), serotonin-1A receptors are located differentially along the midbrain DR. There is a strong main effect of rostral-to-caudal level for the entire DR as well as for each subnucleus (Table 2; Fig. 2). For the entire DR the autoradiographic density of serotonin-1A receptors at the middle levels of the midbrain (levels D and E) is nearly twice that detected more rostrally or caudally. When subnuclei of the DR are examined, the greatest amount of $\left[{ }^{3} \mathrm{H}\right] 8$ OH-DPAT binding occurs in the DRvl and DRv subnuclei at levels $\mathrm{E}$ and $\mathrm{F}$, where serotonin-1A receptors are observed at $\sim 600 \mathrm{fmol} / \mathrm{mg}$ of protein. The density of serotonin-1A receptors in the DRd and DRif is approximately one-half that of the DRvl and DRv.

There was a statistically significant main effect of subject group for the entire DR as well as for DRd and DRvl subnuclei (Table 2; Fig. 2) (ANOVA for repeated measures). Within the entire $\mathrm{DR}$, the DRd, and the DRvl the significant increase in serotonin-1A receptors in depressed suicides ranged from 5 to $30 \%$, from 11 to $34 \%$, and from 11 to $13 \%$, respectively, depending on the rostral-to-caudal level. There was a trend toward a 


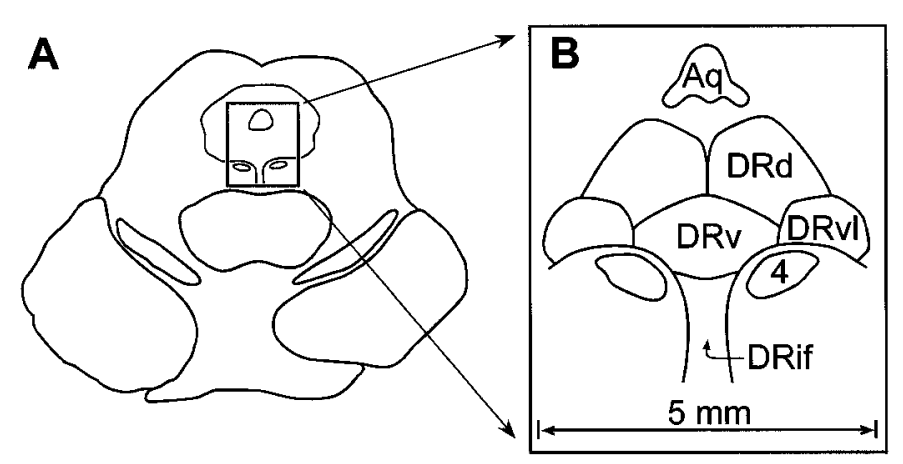

Figure 1. Schematic drawings of the human dorsal raphe nucleus (DR). The drawing in $A$ represents a transverse section of the midbrain at the level of the inferior colliculus. The boxed area depicts the location of the DR in the ventral region of the central gray matter. $B$ is an enlargement of the boxed area in $A$ and demonstrates the cerebral aqueduct $(A q)$, the nucleus of the trochlear nerve (cranial nerve 4$)$, and the dorsal $(D R d)$, ventral $(D R v)$, ventrolateral $(D R v l)$, and interfascicular (DRif) subnuclei of the DR.

significant increase in serotonin-1A receptors in the DRv, but it did not reach statistical significance. The main effect of subject group is demonstrated in colorized digital autoradiograms from four representative levels of a depressed suicide victim and the matched control (Fig. 3). The pattern of results of increased serotonin-1A receptors in depressed suicides was essentially the same when an ANCOVA was performed with age and postmortem interval as covariates (data not shown).

The overall pattern of the rostral-to-caudal distribution of serotonin-1A receptors within the midbrain DR was studied in both subject groups by examining level-by-group interactions. For the entire DR as well as for the subnuclei, including the DRd, $\mathrm{DRv}$, and DRvl, the overall pattern of the rostral-to-caudal distribution of serotonin-1A receptors along the midbrain (i.e., the shape of the curves) did not differ between controls and suicide victims (Table 2). The interaction of level-by-group was statistically significant only for the DRif, although follow-up Student's $t$ tests did not reveal a statistically significant group effect at any single level of the DRif (Table 2).

\section{DISCUSSION}

The binding of $\left[{ }^{3} \mathrm{H}\right] 8-\mathrm{OH}-\mathrm{DPAT}$ to serotonin-1A receptors was increased significantly in the midbrain DR of suicide victims with major depression as compared with psychiatrically normal control subjects. The increase in serotonin-1A receptors was detected within the entire cross section of the midbrain DR and specifically localized to the DRd and DRvl subnuclei. Our evidence in these subjects indicates that major depression, suicide, or the combination of these two factors is related to a significant and consistent increase in serotonin-1A receptors at several levels along the midbrain DR. It remains to be determined whether the increase in $\left[{ }^{3} \mathrm{H}\right] 8-\mathrm{OH}-\mathrm{DPAT}$ binding in the midbrain DR of depressed suicides is an increase in receptor number $\left(B_{\max }\right)$ or affinity $\left(K_{\mathrm{D}}\right)$. The design of the current autoradiography study did not permit a determination of binding maxima.

Several groups have examined serotonin-1A receptors located in prefrontal cortex in suicide victims; however, a clear picture has not emerged. Arango et al. (1995) reported increases in radioligand binding to serotonin-1A receptors in ventrolateral prefrontal cortex of suicide victims. Other studies in suicide victims who were characterized psychiatrically report no change in
serotonin-1A receptors in other regions of prefrontal cortex (Arranz et al., 1994; Lowther et al., 1997; Stockmeier et al., 1997). In contrast to presynaptic serotonin-1A receptors in the DR, serotonin-1A receptors in prefrontal cortex are located postsynaptically, and their involvement in depression and suicide awaits further clarification.

Potential limitations of the current study include the use of retrospective informant-based data for psychiatric determinations, comorbid psychoactive substance use disorders, and the potential effects of medications. In a recent validation of the psychological autopsy technique, Kelly and Mann (1996) reported a $91 \%$ agreement between DSM-III-R diagnoses made antemortem by treating clinicians and informant-based diagnoses made postmortem. The current study is one of few postmortem studies in suicide in which retrospectively collected psychiatric information is presented for both the experimental and control groups. In our selection of subjects we attempted to rule out any contribution of a psychoactive substance use disorder such as alcohol dependence or abuse to serotonin-1A receptors in the midbrain. Only one suicide victim ever met criteria for alcohol dependence (15 years before death). Furthermore, of the two control subjects and three suicides that at one time met criteria for alcohol abuse, between 2 and 24 years had elapsed between the end of the alcohol abuse and the deaths. Two suicide victims were exposed to benzodiazepine medications at or about the time of their deaths; however, chronic treatment with diazepam does not alter the function of the serotonin-1A autoreceptor in the DR (Wilson and Gallager, 1988).

Alterations in serotonin-1A receptors in depressed suicide victims may be related to exposure to antidepressant medications. Two of the suicide victims were taking an antidepressant medication in the last month of life, and two others had prescriptions for antidepressant medications in the year preceding their deaths. There was no evidence in blood or urine of the recent presence of these medications or their metabolites. Because not all of the subjects had recent exposure to antidepressant medications, it appears that the increase in serotonin-1A receptors is related to the depression and/or suicide. Furthermore, chronic treatment of rats with SSRIs, monoamine oxidase inhibitors, or novel anxiolytics with antidepressant qualities either decreases or has no effect on $\left[{ }^{3} \mathrm{H}\right] 8-\mathrm{OH}-\mathrm{DPAT}$ binding to serotonin-1A receptors in midbrain (Welner et al., 1989; Gobbi et al., 1991; Hensler et al., 1991; Fanelli et al., 1992; Burnet et al., 1994; Le Poul et al., 1995).

The role that serotonin-1A receptors in the DR plays in depression and suicide may be related to the location of these receptors on serotonin neurons and the ability of these receptors to regulate the electrical activity of serotonin neurons. The serotonin-1A receptor protein is synthesized by serotonin neurons in the DR, and immunohistochemical evidence reveals that nearly all of these receptors are located on the perikarya and dendrites of serotonin neurons (Sotelo et al., 1990; Miquel et al., 1992). The serotonin-1A receptor has been classified functionally as an inhibitory autoreceptor, because the firing rate of serotonin neurons in the DR is inhibited by the direct application of 8-OH-DPAT, a serotonin-1A receptor agonist, into the DR (Sprouse and Aghajanian, 1986). Thus, the observed increase in presumably inhibitory serotonin-1A receptors in the DR of suicide victims with major depression may provide pharmacological evidence for diminished activity of serotonin neurons in these subjects.

In the study of the human DR, it is important to identify comparable rostral-caudal levels for biological comparisons be- 
Table 2. Analysis of effects of rostral-caudal level and diagnostic group on serotonin-1A receptors in the dorsal raphe of 10 pairs of suicide victims with major depression and normal control subjects

\begin{tabular}{lrrr} 
Region & Level $F$, df, $p$ & Group $F$, df, $p$ & Level $\times$ group interaction, $F$, df, $p$ \\
\hline Entire DR & $69.2,(4,36), 0.001$ & $7.8,(1,36), 0.021$ & $1.8,(4,36), 0.159$ \\
DR dorsal & $16.2,(3,27), 0.001$ & $15.3,(1,27), 0.004$ & $2.4,(3,27), 0.082$ \\
DR ventrolateral & $8.6,(2,18), 0.002$ & $14.8,(1,18), 0.004$ & $0.03,(2,18), 0.974$ \\
DR ventral & $15.0,(3,27), 0.001$ & $3.5,(1,27), 0.092$ & $0.8,(3,27), 0.524$ \\
DR interfascicular & $12.8,(4,36), 0.001$ & $0.8,(1,36), 0.395$ & $2.9,(4,36), 0.034$
\end{tabular}

DR, Dorsal raphe nucleus.

Figure 2. The distribution of $\left[{ }^{3} \mathrm{H}\right] 8$-hydroxy-2-(di$n$-propyl)aminotetralin binding to serotonin-1A receptors in the entire midbrain dorsal raphe (DR) or various subnuclei along rostral-to-caudal levels of the midbrain from 10 pairs of suicide victims with major depression and age-matched psychiatrically normal control subjects. The abscissa represents 0.5 $\mathrm{mm}$ levels through the midbrain, with rostral levels located to the left. The ordinate represents $\left[{ }^{3} \mathrm{H}\right] 8$ OH-DPAT binding (fmol/mg protein) to serotonin-1A receptors. See Materials and Methods for a description of the criteria used for delineating the rostral-to-caudal levels. Serotonin-1A receptors were enhanced significantly in depressed suicide victims (statistically significant main effect of subject group) in the entire $\operatorname{DR}(A ; p<0.021)$ and in ventrolateral $(B ; p<0.004)$ and dorsal $(C ; p<0.004)$ subnuclei, but not in interfascicular $(D)$ or ventral $(E)$ subnuclei, as compared with psychiatrically normal control subjects.

tween groups of subjects. Serotonin-containing neurons within the human DR have been grouped into five subnuclei on the basis of neuronal morphology and density (Baker et al., 1990, 1991), and the locations and boundaries of these subnuclei vary along the extent of the midbrain. In the current study there was a strong influence on radioligand binding of the rostral-caudal level for the entire DR as well as for each subnucleus. Consequently, sections were collected at $0.5 \mathrm{~mm}$ intervals, landmarks were used to identify the levels, and anatomically equivalent rostral-caudal levels were examined in the subject groups.
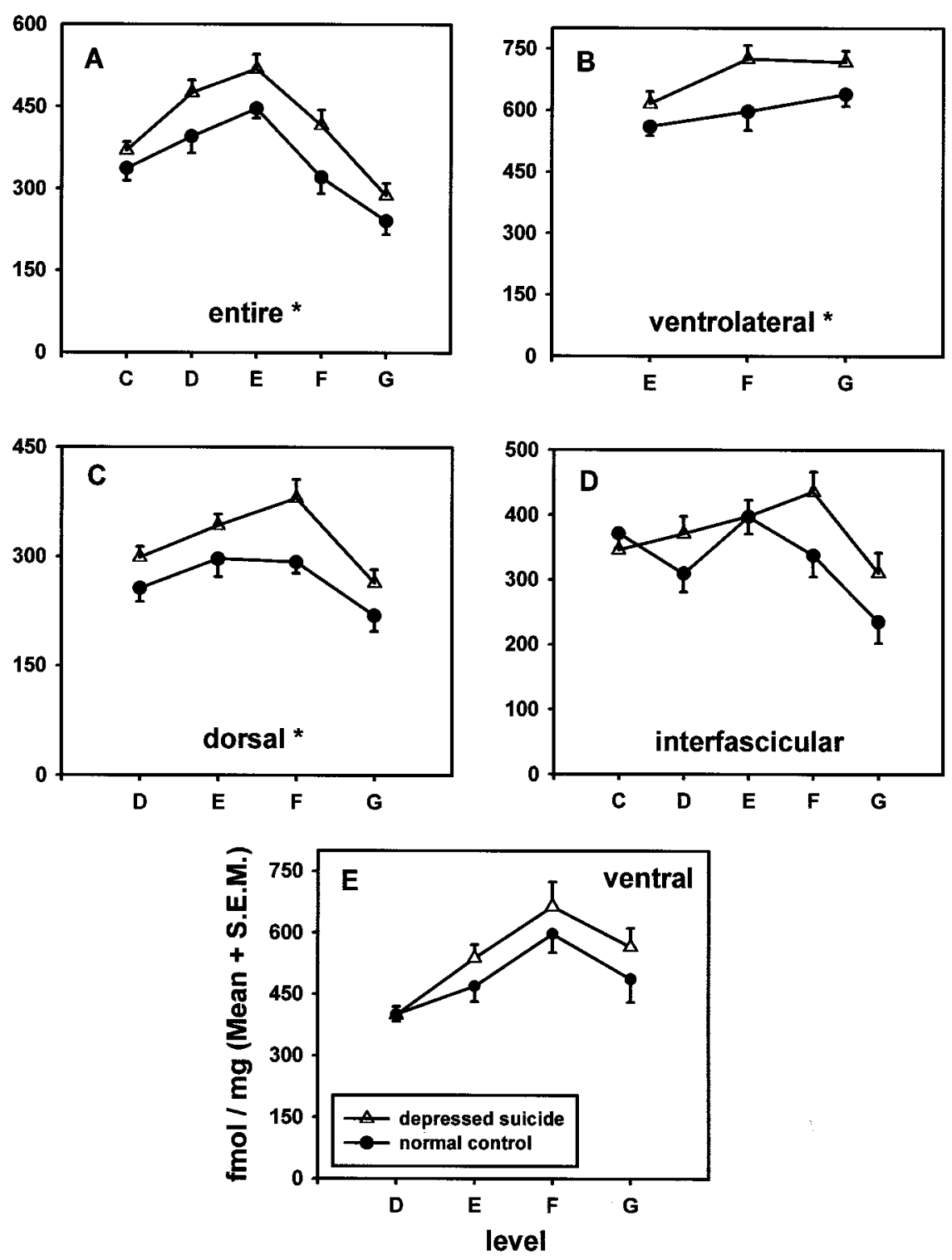

Functional abnormalities detected in prefrontal cortex in depression may be related to abnormalities in specific subregions of the brainstem DR. A coarse topographic organization has been described for the primate DR as related to its target areas in the cerebral cortex. Wilson and Molliver (1991) have observed that clusters of neurons in the DR project to different cortical association areas, and they propose that clusters of neurons may be related to different higher functions. For example, tract-tracing studies in nonhuman primates reveal that many of the DR neurons projecting to the dorsolateral prefrontal cortex originate in 


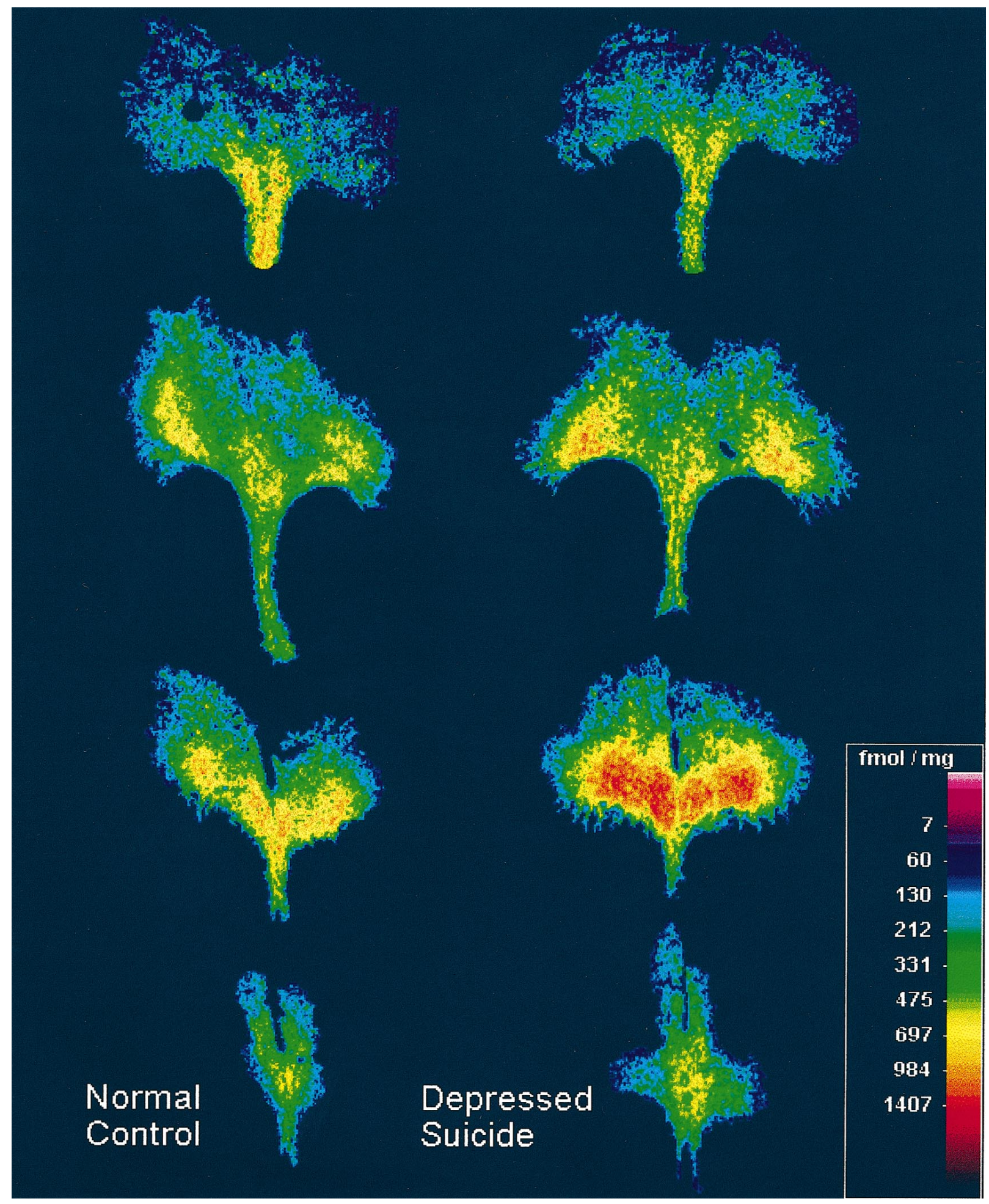

Figure 3. $\quad\left[{ }^{3} \mathrm{H}\right] 8$-hydroxy-2-(di- $n$-propyl)aminotetralin binding to serotonin-1A receptors in the midbrain dorsal raphe (DR) from a representative control subject that was psychiatrically normal (left) and an age-matched suicide victim with major depression (right). The control subject was the 27-yr-old male, and the suicide victim was the 30-yr-old male (see Table 1). The digitized autoradiograms of the DR are shown at four rostral-to-caudal levels of the midbrain, with the upper images located more rostrally. Note the enhanced radioligand binding to serotonin-1A receptors in the depressed suicide victim, as evidenced by greater numbers of orange and red pixels in the images in the right column. The distance across the widest portion of the $\mathrm{DR}$ is $\sim 5 \mathrm{~mm}$. 
the midbrain DR. In a recent functional imaging study of subjects with major depression who responded to SSRIs, an acute depletion of the serotonin precursor tryptophan resulted in a relapse in depressive symptoms and a decrease in brain metabolism in dorsolateral prefrontal cortex (Bremner et al., 1997). It is interesting to speculate that altered function of serotonin-1A autoreceptors on serotonin cell bodies in the midbrain DR in major depression may be related to brain metabolism affected by tryptophan depletion in dorsolateral prefrontal cortex in major depression. Postsynaptic serotonin-1A receptors and serotonergic fibers from the midbrain DR are highly concentrated in outer layers of prefrontal cortex (Smiley and Goldman-Rakic, 1996; Stockmeier et al., 1997). It remains to be determined whether postsynaptic serotonin-1A receptors in dorsolateral prefrontal cortex are altered in the same suicide victims with major depression that demonstrate increased serotonin-1A autoreceptors in the midbrain DR.

Serotonin-1A receptors in the midbrain DR may be critical to the therapeutic effect of some antidepressant treatments, as revealed by electrophysiological experiments. Serotonin-1A receptors in the DR are desensitized by the repeated treatment of experimental animals with a monoamine oxidase inhibitor or SSRI (Blier et al., 1986; Chaput et al., 1988), and that desensitization is coupled with a facilitation of serotonin output in the frontal cortex (Invernizzi et al., 1994). Thus, the therapeutic action of some antidepressant treatments in humans may involve the facilitation of serotonin neurotransmission in prefrontal cortex in response to desensitization of inhibitory serotonin-1A autoreceptors in the midbrain DR (Blier and De Montigny, 1994). In this study the observation of increased serotonin-1A receptors in the midbrain DR of suicide victims with major depression is consistent with the hypothesis that the therapeutic effect of antidepressant medications may involve at least physiological desensitization (if not downregulation) of these receptors on serotonin neurons.

It has been suggested that serotonin-1A autoreceptors in the midbrain play a role in hastening the antidepressant effect of SSRIs (Artigas et al., 1996). Two open-label studies reported that pindolol, an antagonist at $\beta$-adrenergic and serotonin-1A receptors, induced a rapid improvement in depressive symptoms in patients treated with an SSRI or monoamine oxidase inhibitor (Artigas et al., 1994; Blier and Bergeron, 1995). Artigas et al. (1996) suggest that the 2 week delay in the onset of the therapeutic benefit of antidepressant medication may be attributable to the ability of an SSRI to increase the extracellular concentration of serotonin in the midbrain DR, thereby activating inhibitory somatodendritic serotonin-1A autoreceptors. As a result of a diminished firing of serotonin neurons, the extracellular concentration of serotonin in the cerebral cortex would be diminished early in the course of SSRI therapy. Cotreatment with pindolol, it was hypothesized, would restore the firing of serotonin neurons by blocking the inhibitory somatodendritic serotonin-1A autoreceptors and increasing extracellular serotonin concentrations in the forebrain, thereby decreasing the latency of the antidepressant response (Blier and Bergeron, 1997). Most, but not all, double-blind placebo-controlled studies of pindolol plus an SSRI support the hypothesis that pindolol accelerates the antidepressant response (Berman et al., 1997; Perez et al., 1997; Tome et al., 1997; Zanardi et al., 1997).

Future studies in subjects with major depression not dying by suicide and in suicide victims not meeting criteria for major depression will help to identify whether increased serotonin-1A receptors in the midbrain DR are associated with suicide per se, major depression, or an interaction between major depression and suicide. The postmortem evidence reported here provides a clear impetus for the continued development of radioligands for the serotonin-1A receptor to be used in positron emission tomography studies of the DR in patients with major depression and/or suicidal behavior (Farde et al., 1997).

\section{REFERENCES}

Aghajanian GK, Sprouse JS, Rasmussen K (1987) Physiology of the midbrain 5-HT system. In: Psychopharmacology: the third generation of progress (Meltzer HY, ed), pp 141-148. New York: Raven.

Alexander BS, Wood MD (1988) $\left[{ }^{3} \mathrm{H}\right] 8-\mathrm{OH}-\mathrm{DPAT}$ labels the 5-hydroxytryptamine uptake recognition site and the 5- $\mathrm{HT}_{1 \mathrm{~A}}$ binding site in the rat striatum. J Pharm Pharmacol 40:888-891.

American Psychiatric Association (1987) Diagnostic and statistical manual of mental disorders, 3rd Ed-Revised. Washington, DC: American Psychiatric Association.

Arango V, Underwood MD, Gubbi AV, Mann JJ (1995) Localized alterations in pre- and postsynaptic serotonin binding sites in the ventrolateral prefrontal cortex of suicide victims. Brain Res 688:121-133.

Arranz B, Eriksson A, Mellerup E, Plenge P, Marcusson J (1994) Brain $5-\mathrm{HT}_{1 \mathrm{~A}}, 5-\mathrm{HT}_{1 \mathrm{D}}$, and 5- $\mathrm{HT}_{2}$ receptors in suicide victims. Biol Psychiatry $35: 457-463$.

Artigas F, Perez V, Alvarez E (1994) Pindolol induces a rapid improvement of depressed patients treated with serotonin reuptake inhibitors. Arch Gen Psychiatry 51:248-251.

Artigas F, Romero L, De Montigny C, Blier P (1996) Acceleration of the effect of selected antidepressant drugs in major depression by $5-\mathrm{HT}_{1 \mathrm{~A}}$ antagonists. Trends Neurosci 19:378-383.

Baker KG, Halliday GM, Tork I (1990) Cytoarchitecture of the human dorsal raphe nucleus. J Comp Neurol 301:147-161.

Baker KG, Halliday GM, Hornung J-P, Geffen LB, Cotton RGH, Tork I (1991) Distribution, morphology, and number of monoaminesynthesizing and substance P-containing neurons in the human dorsal raphe nucleus. Neuroscience 42:757-775.

Becker G, Becker T, Struck M, Lindner A, Burzer K, Retz W, Bogdahn U, Beckmann H (1995) Reduced echogenicity of brainstem raphe specific to unipolar depression: a transcranial color-coded real-time sonography study. Biol Psychiatry 38:180-184.

Berman RM, Darnell AM, Miller HL, Anand A, Charney DS (1997) Effect of pindolol in hastening response to fluoxetine in the treatment of major depression: a double-blind, placebo-controlled trial. Am J Psychiatry 154:37-43.

Beskow J, Gottfries CG, Roos BE, Winbald B (1976) Determination of monoamine and monoamine metabolites in the human brain: postmortem studies in a group of suicides and in a control group. Acta Psychiatr Scand 53:7-20.

Blier P, Bergeron R (1995) Effectiveness of pindolol with selected antidepressant drugs in the treatment of major depression. J Clin Psychopharmacol 15:217-222.

Blier P, Bergeron R (1997) Early onset of therapeutic action in depression and greater efficacy of antidepressant treatments: are they related? Int Clin Psychopharmacol 12:S21-S28.

Blier P, De Montigny C (1994) Current advances and trends in the treatment of depression. Trends Pharmacol Sci 15:220-226.

Blier P, De Montigny C, Azzaro AJ (1986) Modification of serotonergic and noradrenergic neurotransmissions by repeated administration of monoamine oxidase inhibitors: electrophysiological studies in the rat central nervous system. J Pharmacol Exp Ther 237:987-994.

Bourne HR, Bunney WEJ, Colburn RW, Davis JM, Shaw DM, Coppen AJ (1968) Noradrenaline, 5-hydroxytryptamine, and 5-hydroxyindoleacetic acid in hindbrains of suicidal patients. Lancet 2:805-808.

Bremner JD, Innis RB, Salomon RM, Staib LH, Ng CK, Miller HL, Bronen RA, Krystal JH, Duncan J, Rich D, Price LH, Malison R, Dey H, Soufer R, Charney DS (1997) Positron emission tomography measurement of cerebral metabolic correlates of tryptophan depletioninduced depressive relapse. Arch Gen Psychiatry 54:364-374.

Burnet, PWJ, Michelson D, Smith MA, Gold PW, Sternberg EM (1994) The effect of chronic imipramine administration on the densities of $5-\mathrm{HT}_{1 \mathrm{~A}}$ and $5-\mathrm{HT}_{2}$ receptors and the abundancies of 5-HT receptor and transporter mRNA in the cortex, hippocampus, and dorsal raphe of three strains of rat. Brain Res 638:311-324. 
Chaput Y, Blier P, De Montigny C (1988) Acute and long-term effects of antidepressant serotonin $(5-\mathrm{HT})$ reuptake blockers on the efficacy of 5-HT neurotransmission: electrophysiological studies in the rat central nervous system. In: Advances in biological psychiatry (Mendlewicz J, van Praag HM, eds), pp 1-17. Basel: Karger.

Cochran E, Robins E, Grote S (1976) Regional serotonin levels in brain: a comparison of depressive suicides and alcoholic suicides with controls. Biol Psychiatry 11:283-294.

Fanelli RJ, McMonagle-Strucko K (1992) Alteration of 5-HT $\mathrm{HA}_{1 \mathrm{~A}}$ receptor binding sites following chronic treatment with ipsapirone measured by quantitative autoradiography. Synapse 12:75-81.

Farde L, Ginovart N, Ito H, Lundkvist C, Pike VW, McCarron JA, Halldin C (1997) PET-characterization of [carbonyl ${ }^{11}$ C]WAY-100635 binding to $5-\mathrm{HT}_{1 \mathrm{~A}}$ receptors in the primate brain. Psychopharmacology (Berl) 133:196-202.

Gobbi M, Cavanus S, Miari A, Mennini T (1991) Effect of acute and chronic administration of buspirone on serotonin and benzodiazepine receptor subtypes in the rat brain: an autoradiography study. Neuropharmacology 30:313-321.

Hensler JG, Kovachich GB, Frazer A (1991) A quantitative autoradiographic study of serotonin-1A receptor regulation: effect of 5,7dihydroxytryptamine and antidepressant treatments. Neuropsychopharmacology 4:131-144.

Invernizzi R, Bramante M, Samanin R (1994) Chronic treatment with citalopram facilitates the effect of a challenge dose on cortical serotonin output: role of presynaptic 5-HT $\mathrm{HT}_{1 \mathrm{~A}}$ receptors. Eur J Pharmacol 260:243-246.

Kelly TM, Mann JJ (1996) Validity of DSM-III-R diagnosis by psychological autopsy: a comparison with clinician ante-mortem diagnosis. Acta Psychiatr Scand 94:337-343.

Korpi ER, Kleinman J, Goodman SI, Phillips I, DeLisi LE, Linnoila M, Wyatt RJ (1986) Serotonin and 5-hydroxyindoleacetic acid in brains of suicide victims: comparison in chronic schizophrenic patients with suicide as cause of death. Arch Gen Psychiatry 43:594-600.

Le Poul E, Laaris N, Doucet E, Laporte A-M, Hamon M, Lanfumey L (1995) Early desensitization of somato-dendritic 5-HT $1 \mathrm{~A}$ autoreceptors in rats treated with fluoxetine or paroxetine. Naunyn Schmiedebergs Arch Pharmacol 352:141-148.

Lloyd KG, Farley IJ, Deck JHN, Hornykiewicz O (1974) Serotonin and 5-hydroxyindoleacetic acid in discrete areas of the brainstem of suicide victims and control patients. Adv Biochem Psychopharmacol 11:387-397.

Lowther S, De Paermentier F, Cheetham SC, Crompton MR, Katona CLE, Horton RW (1997) 5- $\mathrm{HT}_{1 \mathrm{~A}}$ receptor binding sites in postmortem brain samples from depressed suicides and controls. J Affect Disord 42:199-207.

Malison RT, Pelton G, Carpenter L, Sanacora G, Haroon E, Potenza M, Berman R, Baldwin RM, Seibyl JS, Price LH, Innis RB, Charney DS (1997) Reduced midbrain serotonin transporter binding in depressed vs. healthy subjects as measured by [ $\left.{ }^{123} \mathrm{I}\right] \beta$-CIT SPECT. Soc Neurosci Abstr 23:1120.

Mann JJ, Malone KM, Sweeney JA, Brown RP, Linnoila M, Stanley B, Stanley M (1996) Attempted suicide characteristics and cerebrospinal fluid amine metabolites in depressed patients. Neuropsychopharmacology 15:576-586.

Miquel MC, Doucet E, Riad M, Adrien J, Vergé D, Hamon M (1992) Effect of the selective lesion of serotoninergic neurons on the regional distribution of 5- $\mathrm{HT}_{1 \mathrm{~A}}$ receptor mRNA in the rat brain. Mol Brain Res 14:357-362.

Montgomery SA (1995) Selective serotonin reuptake inhibitors in the acute treatment of depression. In: Psychopharmacology: the fourth generation of progress (Bloom FE, Kupfer DJ, eds), pp 1043-1051. New York: Raven.
Nordstrom P, Asberg M (1992) Suicide risk and serotonin. Int Clin Psychopharmacol 6[Suppl 6]:12-21.

Pare CMB, Yeung DPH, Price K, Stacey RS (1969) 5Hydroxytryptamine, noradrenaline, and dopamine in brainstem, hypothalamus, and caudate nucleus of controls and of patients committing suicide by coal-gas poisoning. Lancet 2:133-135.

Pérez V, Gilaberte I, Faries D, Alvarez E, Artigas F (1997) Randomised, double-blind, placebo-controlled trial of pindolol in combination with fluoxetine antidepressant treatment. Lancet 349:1594-1597.

Peterfy G, Pinter EJ, Pattee CJ (1976) Psychosomatic aspects of catecholamine depletion: comparative studies of metabolic, endocrine, and affective changes. Psychoneuroendocrinology 1:243-253.

Quetsch RM, Achor RWP, Litin EM, Faucett RL (1959) Depressive reactions in hypertensive patients, a comparison of those treated with rauwolfia and those receiving no specific antihypertensive treatment. Circulation 19:366-375.

Shaw DM, Camps FE, Eccleston EG (1967) 5-Hydroxytryptamine in the hind-brain of depressive suicides. Br J Psychiatry 113:1407-1411.

Smiley JF, Goldman-Rakic PS (1996) Serotonergic axons in monkey prefrontal cerebral cortex synapse predominantly on interneurons as demonstrated by serial section electron microscopy. J Comp Neurol 367:431-443.

Sotelo C, Cholley B, El Mestikawy S, Gozlan H, Hamon M (1990) Direct immunohistochemical evidence of the existence of $5-\mathrm{HT}_{1 \mathrm{~A}}$ autoreceptors on serotoninergic neurons in the midbrain raphe nuclei. Eur J Neurosci 2:1144-1154.

Spitzer RL, Endicott J (1978) Schedule for affective disorders and schizophrenia (SADS), 3rd Ed. New York: New York State Psychiatric Institute.

Sprouse JS, Aghajanian GK (1986) (-)-Propranolol blocks the inhibition of serotonergic dorsal raphe cell firing by $5-\mathrm{HT}_{1 \mathrm{~A}}$ selective agonists. Eur J Pharmacol 128:295-298.

Sprouse JS, McCarty DR, Dudley MW (1993) Apparent regional differences in $5-\mathrm{HT}_{1 \mathrm{~A}}$ binding may reflect $\left[{ }^{3} \mathrm{H}\right] 8-\mathrm{OH}-\mathrm{DPAT}$ labeling of serotonin uptake sites. Brain Res 617:159-162.

Stockmeier CA, Shapiro LA, Haycock JW, Thompson PA, Lowy MT (1996) Quantitative subregional distribution of serotonin-1A receptors and serotonin transporters in the human dorsal raphe. Brain Res 727:1-12.

Stockmeier CA, Dilley GE, Shapiro LA, Overholser JC, Thompson PA, Meltzer HY (1997) Serotonin-1A and -2A receptors in prefrontal cortex and hippocampus of suicide victims with major depression. Neuropsychopharmacology 16:162-173.

Tome MB, Isaac MT, Harte R, Holland C (1997) Paroxetine and pindolol: a randomized trial of serotonergic autoreceptor blockade in the reduction of antidepressant latency. Int Clin Psychopharmacol 12:81-89.

Welner SA, De Montigny C, Desroches J, Desjardins P, Suranyi-Cadotte BE (1989) Autoradiographic quantification of serotonin-1A receptors in rat brain following antidepressant drug treatment. Synapse 4:347-352.

Wilson MA, Gallager DR (1988) GABAergic subsensitivity of dorsal raphe neurons in vitro after chronic benzodiazepine treatment in vivo. Brain Res 473:198-202.

Wilson MA, Molliver ME (1991) The organization of serotonergic projections to cerebral cortex in primates: retrograde transport studies. Neuroscience 44:555-570.

Zanardi R, Artigas F, Franchini L, Sforzini L, Gasperini M, Smeraldi E, Perez J (1997) How long should pindolol be associated with paroxetine to improve the antidepressant response? J Clin Psychopharmacol 17:446-450. 